Guilt by Association:

Contrasting views on the fairness of 'secret trials' of 'terrorists'1

\author{
Dr. John R Campbell \\ Department of Anthropology \& Sociology \\ School of Oriental \& African Studies, London
}

\begin{abstract}
This chapter examines key aspects of procedural justice which arise when individuals are detained under counter-terrorist legislation in the United Kingdom. The task requires a careful look at the legal proceedings which individuals who are detained under control orders/TPIMs are subject to, namely a 'secret trial' and their dependence on the work of Special Advocates to disclose/reveal the Home Office case against them and judges whose scope in deciding appeals is extremely limited. An examination of the procedural measures adopted in these cases reveals the very different way that secret trials operate to that of public criminal trials. At the same time, and by contrast with anthropology, I argue that the disciplinary training of lawyers predisposes them to accept a narrow approach to 'facts' and a tendency to assign liability for actions in ways which facilitate secret legal processes. In contrast anthropologists, in their attempt to see the work of law more holistically, seek to probe, unsettle and question the apparent certainties which underlay legal practice and to ask whether such procedures are fair and just.
\end{abstract}

Key words: anthropology, law, control orders/TPIM, Closed Material Proceedings, guilt by association.

John Rawls, ${ }^{2}$ sparked considerable interest in procedural and natural justice which has been taken up by legal scholars and practicing lawyers and jurists but has not been

\footnotetext{
${ }^{1}$ I am grateful to John Jackson and Graham Hudson for their detailed comments on an earlier version of this paper which has been presented and discussed at various conferences and seminars. I would also like to thank James Simeon for his detailed comments on the chapter.

${ }^{2}$ John Rawls, A Theory of Justice (New York: Oxford University, 1971 [1999]).
} 
explored comparatively or ethnographically by anthropologists. Laura $\mathrm{Nader}^{3}$, a legal anthropologist, has argued that taken for granted phrases such as 'the rule of law' conceal more than they reveal and that anthropologists should question normative assumptions to understand the way that the law may be experienced as a form of ‘injustice'. Anthropologists have long recognized that the disciplinary training of lawyers and anthropologists imbues each profession with distinctive paradigms and assumptions. ${ }^{4}$ Anthropological research has examined the way that lawyers are trained to think ${ }^{5}$, the very different ways that lawyers/judges and anthropologists approach 'facts', ${ }^{6}$ the disjuncture between lawyer and litigant assumptions of fairness ${ }^{7}$ and the importance of different 'styles of speaking' in court ${ }^{8}$ among other things.

I draw on this literature to examine legal practices and procedures which I observed during the 'secret trial' of a suspected terrorist in which I was instructed as a ‘country expert'. By carefully examining legal practice and procedure I examine how lawyers locate liability and arrive at a judgment - guilty or not guilty - in ways that sharply contrast with anthropological methods and training which require one to suspend belief to search for an explanation. In short, I contrast the normative, judgmental approach taken by law with the anthropological requirement of situating a

\footnotetext{
${ }^{3}$ Laura Nader, 'The words we use: justice, human rights, and the sense of injustice', in K. Clarke \& M. Goodale. Eds. Mirrors of Justice (New York: Cambridge University Press: N.Y. 2010), 316-331.

${ }^{4}$ Kandel, R. 'How lawyers and anthropologists think differently', Annals of Anthropological Practice (1992), 1-20.

${ }^{5}$ J. Conley, 'Review: Can You Talk like a Lawyer and Still Think like a Human Being? Mertz's the Language of Law School', Law \& Social Inquiry 34, 4 (2009), 983-2015.

${ }^{6}$ A. Good, 'Expert evidence in asylum and human rights appeals: An expert's view', International Journal of Refugee Law 16, 3 (2004), 358-380.

${ }^{7}$ J. Conley \& W. O’Barr, 'Hearing the hidden agenda: The ethnographic investigation of procedure', Law \& Contemporary Problems 51, 4 (1988), 181-197. ${ }^{8}$ J. Conley, J., W. O’Barr \& E. Lind, 'The power of language: presentational style in the courtroom', Duke Law Journal (1978), 1375-1399.
} 
case in a wider social context to understand complex legal processes and the roles played by the state, lawyers, judges and defendants.

In recent years, terrorist attacks have provided legislators with the authority to fundamentally reshape the quality of justice and the work of the law in Europe and North America. This is especially evident in the field of immigration where strategic concerns about national security and terrorism have been used to rewrite law, pass new legislation and reinforce the discretionary power of the executive in ways that would have been unthinkable before $9 / 11 .^{9}$

Quite apart from the use of counter-terrorism measures in colonial Kenya, Malaysia, and elsewhere, Britain has also used counter-terrorism legislation to ban individuals, prescribe organizations and criminalize behavior in Northern Ireland. This history has informed recent legislation ${ }^{10}$ including The Terrorism Act (2000). ${ }^{11}$ Indeed the Government continues to enact legislation aimed at enhancing the security of the UK including The Prevention of Terrorism Act (2005) ${ }^{12}$ (which introduced control orders), The Terrorism Act (2006) ${ }^{13}$ and well as laws which anticipate terrorist events such as the 'Terrorism Prevention and Investigation Bill' and the 'Draft Enhanced Terrorism and Investigation Measures Bill' ${ }^{14}$ The latter measures are supposed to be a 'less intrusive system of terrorism and prevention measures' that 'will protect the public from individuals who pose a real terrorist threat' but who cannot be prosecuted or, in the case of nationals suspected of terrorism, cannot be

\footnotetext{
${ }^{9}$ See: E. Brouwer, 'Immigration, asylum and terrorism: A changing dynamic. Legal and practical developments in the EU response to the terrorist attacks of 11.09", European Journal of Migration and Law 4 (2003), 399-424; and E. Boyle \& E. Busse, 'Institutional vulnerability and opportunity” Immigration and America's "War on Terror”, Law \& Social Enquiry 31: 4 (2006), 947-74.

${ }^{10}$ See: https://www.legislation.gov.uk/all?title=terrorism

${ }^{11}$ See: https://www.legislation.gov.uk/ukpga/2000/11/contents

12 See: https://www.legislation.gov.uk/ukpga/2005/2/contents

${ }^{13}$ See: https://www.legislation.gov.uk/ukpga/2006/11/contents

${ }^{14}$ See: https://www.parliament.uk/business/committees/committees-a-z/jointselect/terrorism-prevention-and-investigation-measures-bill/publications/
} 
deported. ${ }^{15}$ Viewed in their entirety, 'counter-terrorism’ legislation has shifted from an attempt to investigate, criminalize and proscribe individuals/organizations operating in the UK to a preemptive, anticipatory attempt to prevent individuals from entering the UK whom the Government suspects may carry out terrorist-related acts.

In what follows I do not offer a line-by-line reading of legislation nor do I look at the voluminous literature on terror-related litigation. Rather, I adopt an anthropological approach informed by an in-depth examination of the case of one individual who was detained under a control order for six years. ${ }^{16}$ This approach requires me to situate the case in a wider legal context to understand the role played by state institutions and key legal actors involved in counter-terrorism hearings. I also seek to understand whether legal procedures are 'fair', how the law affects a person held under a control order/‘TPIM notice’ and whether such measures contribute to the very thing they seek to prevent. ${ }^{17}$

In most areas of law defendants and their legal representative know the case they will have to answer in court; this is not true in control order/TPIM cases because the 'evidence' relied upon by the Secretary for the Home Department (SSHD) is kept secret, i.e., it is not disclosed. Furthermore, under the Prevention of Terrorism Act

\footnotetext{
${ }^{15}$ See: http://www.homeoffice.gov.uk/publications/about-us/legislation/tpim-bill/.

16 The case method in the study of law is a well-known way of examining aspects of a single case from which it is possible to generalize to other cases; see: A.L. Epstein. 'The case method in the field of law', in A.L. Epstein. Ed. The Craft of Social Anthropology (Tavistock: London. 1967), 205-230.

${ }^{17}$ In SSHD v AF (no. 3) [2009] UKHL 29, Lord Hoffman stated that there were 'strong policy considerations that support a rule that a trial procedure can never be fair if a party to it is kept in ignorance of the case against him'. He based his conclusion on two reasons. First, there will be many cases where it is impossible for the court to be confident that disclosure will make no difference. Second, if individuals are effectively placed under house arrest without being told the gist of the case against them, feelings of resentment will be felt not only by the controlee but also by his family, friends and broader community' (my emphasis, cited in A. Kavanagh, 'Special advocates, control orders and the right to a. know', The Modern Law Review 73, 5 (2010), 841.
} 
$(2005)^{18}$ - which has been superseded by the Terrorism Prevention and Investigation Measures Act (2011) ${ }^{19}$ and the Counter Terrorism and Security Act (2015) ${ }^{20}$ - the courts are prevented from adequately reviewing and, if necessary, quashing/setting aside a case and releasing the defendant.

Given the clear temporal, legal and geographic shift reflected in recent terrorist legislation which seeks to anticipate and prevent offences before they are committed, ${ }^{21}$ it is useful to view this area of law as a hybrid politico-legal field characterized by its own blurred and chameleon-like processes which fuse together criminal law, immigration law and national security considerations. This situation has arisen because, in the face of an expanded perception of threat, legislators tell us that we need to re-calibrate the relation between liberty and security so that security concerns trump individual liberty. ${ }^{22}$ This rebalancing can be observed in the way that terrorist legislation increasingly 'targets people on the basis of whom they know and associate with rather than what they have done ${ }^{23}$ which reflects the growing extent to which politicians, rather than the courts, assess 'risk'.

Nowhere is this better seen than in the operation of 'Closed Material Proceedings' (CMP) or 'secret trials, ${ }^{24}$ which individuals who are arrested and detained under counter terrorism laws are subjected to. Secret trials, which are

\footnotetext{
${ }^{18}$ See: https://www.legislation.gov.uk/ukpga/2005/2/contents

${ }^{19}$ See: http://www.legislation.gov.uk/ukpga/2011/23/contents/enacted

${ }^{20}$ See: http://www.legislation.gov.uk/ukpga/2015/6/contents/enacted

${ }^{21} \mathrm{~J}$. McCulloch, 'Pre-Crime and counter-terrorism. Imagining a future crime in the War on Terror', The British Jo. of Criminology 49, 5 (2009), 628-645

${ }^{22}$ L. Zedner, 'Securing liberty in the face of terror: Reflections from Criminal Justice', Jo. of Law \& Society 32, 4 (2005), 507-533

${ }^{23}$ McCulloch, 'Pre-Crime', 628.

${ }^{24}$ CMPs operate in 21 different contexts which rely on special advocates to ensure that state evidence against a defendant is disclosed where they provide a 'veneer of respectability' to legal proceedings. See: J. Jackson, 'The role of special advocates: Advocacy, due process and the adversarial tradition', International Jo. of Evidence and Proof 20, 4 (2016), 345.
} 
distinct from cases in which individuals are publicly tried in a criminal court, have serious implications for a defendant's right to a fair trial including: (a) the right to be tried by an independent and impartial tribunal; (b) the right to have ones' case defended on the basis of established facts and the law; and, (c) the right to know the case against you and the right to respond to that case in an open court. ${ }^{25}$

Central to my task is the need to translate the 'ideology' of law - the language employed by lawyers, the courts and the Home Office (the government department responsible for immigration and passports, drugs policy, counter-terrorism and policing) - to reveal the underlying power relations at work. Secret trials need to be understood as an uneven contest whose outcome is influenced by many inter-related factors including: a rapidly changing legislative process; lobbying in Parliament and the House of Lords and efforts by the Home Office to create primary legislation (e.g., to reverse High Court decisions, pursue litigation, overturn policy or case law, and to allow the SSHD’s to use her executive power to issue new immigration rules and polices). ${ }^{26}$

Secret trials involve actors/institutions which possess differential power and resources - the Home Office, police and prison officials, immigration officials, Special Advocates, the Special Immigration Appeals Commission (SIAC), the Court of Appeal and legally aided lawyers - whose work decides the fate of individuals accused of terrorism. Legal appeals against a control order/TPIM are not level politico-legal contests because the Home Office relies on its access to substantially

${ }^{25}$ G. Hudson, n.d. "Behind Closed Doors: The judicial administration of 'secret trials' in Canada.” Paper presented at International Association for the Study of Forced Migration, University of Macedonia, Thessaloniki, Greece, 24-27 July 2018. ${ }^{26}$ J. Campbell, Bureaucracy, Law and Dystopia in the United Kingdom's Asylum System (Routledge: NY, 2017), Chapters 2 \& 3. 
greater 'resources' (including its use of the media) and its ability to rewrite 'the rules of the game' to up the ante and win judicial/political contests. ${ }^{27}$

Regardless of the unevenness of the contest, lawyers and judges uphold an ideology of 'the rule of law' which can loosely be described as flowing from the principles of fairness, equality before the law and human dignity. This principle is actualized by an 'independent judiciary’ which, in theory, has the right to scrutinize and interpret legislation and to review the decisions of lower courts and state officials. ${ }^{28}$ However, this ideology obscures what happens.

Section (i) of this chapter provides a précis of the events leading up to $\mathrm{Mr}$. $\mathrm{O}_{2}$ 's ${ }^{29}$ appeal; it also sets out the restrictions imposed on him by the Home Office. I adopt the pseudonym of ' $\mathrm{O} 2$ ' to emphasize the fact that suspected terrorists provide the government with a rationale for its argument that enhanced security arrangements are required to protect the public (i.e., if there are no suspects, there is no oxygen/O2 and, thus, no rationale for the law). I then briefly discuss my involvement in the case and my research methodology. Section (ii) examines at the High Court hearing of O2's appeal against the control order. I focus on the tactics employed by the SSHD. Section (iii) looks at the role played by the judiciary who adjudicate control order appeals. Considering the extensive powers held by the SSHD, as revealed in the case of Mr. O2, I conclude that terrorist legislation has rebalanced the scales of justice in favor of security over individual liberty and that, by anthropological standards, the legal proceedings analyzed in this chapter are unfair.

\footnotetext{
${ }^{27}$ F. G. Bailey, Stratagems and Spoils. A Social Anthropology of Politics (Schocken Books: N.Y. 1969).

${ }^{28}$ Lord Woolf, 'The rule of law and a change in the constitution', The Times, 3 March 2004 at: http://www.timesonline.co.uk/tol/news/article1036741.ece?

${ }^{29}$ To protect the identity of the defendant and his family I have stripped all personal information from the text and I have deleted reference material, including court decisions and media coverage which could be used to identify him.
} 


\section{Mr. $\mathrm{O}_{2}$ and the Secretary of State's allegations}

$\mathrm{O}_{2}$ arrived in the UK with his family and claimed asylum in the early 1990s; in 1999 he and his family were granted indefinite leave to remain which permitted them to settle in England. In late 2000, he began to attend mosque and in 2001 he converted from Orthodox Christianity to Islam. In mid-2004, 02 went on a camping trip with acquaintances and in 2005, together with a small group of friends, he traveled to Mogadishu, Somalia, to practice 'dawah'. ${ }^{30}$

While he was in Somalia members of his family were arrested in connection with a failed terrorist attack. However, rather than returning to the UK $0_{2}$ went to Ethiopia where he remained with his Ethiopian wife until December 2006. On seeking to board a flight to the UK he was arrested, detained and interrogated by the Ethiopian authorities for two weeks. When he was released he flew to London in December 2006 and was detained on arrival. The SSHD initially refused him entry into the UK 'on the grounds that his exclusion was conducive to the public good' and she also cancelled his Indefinite Leave to Remain (ILR). He was arrested and questioned at Paddington Green Police Station, London, by the police and MI5 and four days later he was transferred to prison.

Initially the Home Office objected to $\mathrm{O}_{2}$ being granted bail. In its 'First Open Statement and Objection to Bail ${ }^{31}$ it argued that: (1) he was 'an Islamic extremist who is strongly assessed to have attended a terrorist training camp in Cumbria'; (2) 'he participated in terrorist training in Somalia'; and, (3) given his 'links to an individual assessed to have attempted to carry out terrorist attacks in London, the Security

${ }^{30} \mathrm{Da}$ 'wa or da'wah is a religious act/obligation imposed on Muslims. According to H. Wehr, A Dictionary of Modern Written Arabic (Arabic-English) (Otto Harassowitz: Wiesbaden. 1979, 365) da'wa means: to wither, wilt, fade; but also to spread, get about, circulate, be spread, be disseminated, be or become widespread ... to propagate, make known etc.' There does not appear to be a uniform expectation as to how a Muslim fulfills this obligation.

${ }^{31}$ This was a ten-page statement sent to counsel for $\mathrm{O}_{2}$ in early 2007. 
Services assess that there is a real risk that $\mathrm{O}_{2}$ would become involved in attack planning in the UK'. The statement justified a refusal to disclose further information because 'damage could be done by disclosure ... [that] would cause real harm to the work of the Security Service'. The statement continued: 'The general nature of those concerns need little elaboration. They are aimed at both protecting the integrity of security and intelligence operations and at protecting the safety and usefulness of those whose work for the Security Services and who provide information to it.' As will become evident, the Home Office had little concrete information about $\mathrm{O}_{2}$, but its suspicions created an inordinate hurdle against which $\mathrm{O}_{2}$ and his legal team struggled to secure bail and to challenge the control order in his High Court and subsequent appeals (when some of the allegations were withdrawn).

Nevertheless, $\mathrm{O}_{2}$ was eventually granted bail on stringent conditions (though he was not released from prison until July because secure accommodation could not be found where he could be monitored by the police). In July 2007 his brother-in-law was convicted of involvement in a failed terrorist attack. In August, the SSHD obtained permission to make a control order ${ }^{32}$ for $\mathrm{O}_{2}$ (see Box A, below). At this point, the SSHD re-instated his ILR and withdrew her decision to remove him from the UK.

In April 2008 O2’s control order was suddenly modified, and more stringent conditions were imposed on him including a requirement that he move 150 miles away from his community and family. While waiting for his appeal, four siblings were charged and convicted under sec. 19 of the Terrorism Act 2000 of failing to inform the police about a possible attack and/or assisting an offender to evade

\footnotetext{
${ }^{32}$ For a list of all the restrictions that the SSHD can impose see A. Carlisle (Lord), Fourth Report of the Independent Reviewer pursuant to Sec. 14(3) of the Prevention of Terrorism Act 2005. (February). 2009.
} 
capture. ${ }^{33}$ In early July his appeal against the imposition of the control order was heard at the Royal Courts of Justice, London.

\section{Insert Box A here}

\section{My involvement in this case}

In early 2007 I was interviewing an immigration case worker as part of a research project aimed at mapping and analyzing the British asylum system. ${ }^{34}$ During the course of the interview, I was asked whether, as a recognized 'country expert, ${ }^{35} \mathrm{I}$ would be willing to assist a client of the firm who was detained in a high security prison under a terrorist control order.

I agreed to assist and was instructed by the firm to help them understand the circumstances of his detention and treatment by the Ethiopian authorities (which the Home Office had not disclosed information about) and to write an expert report for his hearing at the High Court. I was given access to all correspondence about the case including: legal representations, correspondence with the Home Office, the appellant's asylum application, ten witness statements made by the appellant and material about the criminal trial against members of his family. I also attended the 'open sections' of O2's appeal at which I took verbatim notes of everything that was said during the proceedings. Later I was given a copy of the official transcript of the open sections of 02 's appeal which enabled me to cross check my notes. I used my notes and the transcript to undertake a detailed analysis of the way that both legal

\footnotetext{
33 This law was not used at the height of Irish Republican terrorism in the UK.

${ }^{34}$ Research was funded by a grant from the UK Economic \& Social Research Council entitled "Refugees and the Law: An ethnography of the British asylum system" (RES062-23-0296). I am indebted to $\mathrm{O}_{2}$ and his legal team for allowing me to follow his case and for giving me access to the transcript of the trial.

${ }^{35}$ Good, Expert Evidence, 2004.
} 
counsels questioned witnesses and how witnesses and the defendant answered questions during the hearing. It is this analysis which forms the basis of the chapter. In July 2008, at the High Court, I was briefly introduced to $\mathrm{O}_{2}$ (this was the only time we met). Near the end of the appeal I was asked to write a second expert report addressing the Special Advocates 'gist' of information which summarized the evidence that was relied upon in the closed hearing against $\mathrm{O}_{2}$. Finally, I attended O2's first appeal at the English Court of Appeal against the decision by the Home Office to alter his bail/control order conditions. From this point onward, I followed the case from a growing distance as his subsequent appeals were handled by different legal teams.

\section{O2’s High Court Appeal, July 2008}

Terrorist legislation limits the power of the court to decide whether the SSHD's decision to impose a control order is lawful. ${ }^{36}$ This means that the court only has the power to 'review' the SSHDs decision to impose a control order to see whether her decision was 'reasonable' in its assessment of his involvement in 'terrorist-related activity' and whether the SSHD's order was properly made 'to protect the public from a risk of terrorism'. The standard of proof which the court applies is 'reasonable suspicion'. ${ }^{37}$ This very low standard of proof is also used to impose 'anti-social

\footnotetext{
${ }^{36}$ See the PTA (2005), parts 2, 3, 7 and 10.

${ }^{37}$ For example, 'A police officer has "reasonable suspicion" when there exists articulable facts or circumstances which would lead a reasonable person to suspect that a crime has been, is being, or will be committed. At this stage, police may detain the suspect for a brief period and perform a frisk ... Refusing a search does not create reasonable suspicion, although acting nervous and answering questions inconsistently can. For this reason, it is best not to answer questions if you have to lie in order to do so ... As a general rule, reasonable suspicion applies to situations where police have reason to believe you're up to something, but they don't know what it is.' At: http://www.knowmyrights.org/knowledgebase/case-law/probable-cause-reasonablesuspicion.
} 
behavior order' (ASBO) ${ }^{38}$ against a nuisance neighbor or to assess whether an individual has 'breached the peace’ (a civil offence); it requires the court to assess whether the individual poses a future risk to the public. In short, the decision to impose a control order must anticipate whether an individual is likely to pose a threat to national security. If the court decides that the SSHDs decision was unreasonable it may quash the order; but the SSHD can reimpose it. ${ }^{39}$

The procedural and evidential rules ${ }^{40}$ which operate in control order hearings differ substantially from criminal and civil proceedings. In the latter two systems the parties to a hearing are on an equal footing and procedures are in place to ensure that the case is dealt with fairly. However, in CMP hearings the court has a duty to ensure that information about the case is not disclosed to the appellant and his legal team if it 'is contrary to the public interest', i.e., if such information might 'harm' the work of the security services that provide the information.

There are serious questions about the 'mosaic' nature and reliability of the undisclosed information ${ }^{41}$ relied on in the closed section of CMP's because it is not 'tested' in open court. To deal with this problem, 'Special Advocates’ (SAs) were created. These are government-vetted barristers whose role is to safeguard the human rights of the accused. As Jackson ${ }^{42}$ has argued, SA's operate in a structurally difficult position: (1) they can make submissions to the Commission (SIAC) in proceedings which the appellant and his representatives are excluded from; (2) in theory they cross examine witnesses in CMP; and, (c) they can make written submissions to the judge.

\footnotetext{
${ }^{38}$ A relatively new offence, see: http://www.homeoffice.gov.uk/anti-socialbehaviour/penalties/anti-social-behaviour-orders/.

${ }^{39}$ PTA sec. 3 (12-14).

${ }^{40}$ See: Statutory Instrument 2003 No. 1034, 'The Special Immigration Appeals Commission (Procedure) Rules, 2003, at: http://www.opsi.gov.uk/si/si2003/20031034.htm.

${ }^{41}$ Interview with Ian McDonald, barrister at Garden Court Chambers (and former Special Advocate) on 27 November 2007.

42 Jackson, The role, 2016, 351-f.
} 
However (d), SA's do not formally 'act' for the accused nor can the accused person appoint their own SA. Furthermore, '[w]hat is unprecedented ... is the prohibition on any communication between the special advocate and the appellant once the Special Advocate is given sight of the closed material'. ${ }^{43}$ In short, once a hearing is about to begin all contact between the SA, the defendant and his lawyer ends.

SAs are supposed to 'test the cogency’ of undisclosed material submitted in the closed sections of the hearing to see if it can be disclosed to the appellant without jeopardizing national security. If the court agrees to their request a 'gist' or 'essence of the case' is released to allow a defendant to respond. ${ }^{44}$ However the SA's ability to perform this role is sharply circumscribed by their structural position. ${ }^{45}$ SA's are also supposed to assist the appellant by advising on the best possible course of action in view of all the evidence. However, the appellant is not obliged to take their advice. There are, therefore, serious questions about the ability of the SA to perform this dual role. $^{46}$

Before turning to $\mathrm{O}_{2}$ 's appeal it is important to observe how his five-day appeal hearing was organized. The appeal began at 10:30 am on a Monday; there was an hour lunch break at about 1 pm; afternoon sessions concluded no later than 5:00

\footnotetext{
${ }^{43}$ Jackson, 'The role’, 353.

44 This is referred to as the SA's disclosure role as opposed to his representational role. The state's evidence is based on intelligence which takes a 'mosaic quality' because it is pieced together from various sources including intercept evidence, covert surveillance, agent reports and material taken from the internet. See: A. Kavanagh, 'Special advocates, control orders and the right to know', The Modern Law Review 73, 5 (2010), 841-842.

${ }^{45}$ In 2004 the role of SA's was sharply criticized because of problems with closed evidence which emerged by accident. The incident led to the resignation of two SAs - one of whom was Ian McDonald - and a Parliamentary enquiry into the operation of SIAC and the use of SAs. See: House of Commons. The operation of the Special Immigration Appeals Commission (SIAC) and the use of Special Advocates (Constitutional Affairs Committee. Seventh Report of Session 2004-05. Vol. 1. Report together with formal minutes). 2005.

${ }^{46}$ See House of Lords (SSHD v MB [2007] EWHC 651 (Admin) on this issue; and A. Sandell, 'Liberty, fairness and the UK control order cases: two steps backward, two steps back’, European Human Rights Law Review 1 (2008) 120-131.
} 
pm. As Box B indicates, the duty placed on the court not to disclose information submitted by the Government means that at least half of the entire hearing was held in closed session from which $\mathrm{O} 2$ and his legal team were excluded.

\section{Insert Box B here}

In examining $\mathrm{O}_{2}$ 's appeal I focus on key aspects of the case including the power of the SSHD to litigate and orchestrate the appeal in a manner which enhances her power. Clearly, the key task confronting $\mathrm{O}_{2}$ 's counsel ${ }^{47}$ was to discover the basis of the SSHDs case against his client. However, when proceedings opened on Monday morning $\mathrm{O}_{2}$ 's counsel was forced to make an application in relation to two reports that had been faxed to $\mathrm{O}_{2}$ ' solicitor late on the preceding Friday. The first report was a police 'interview' with $\mathrm{O}_{2}$ that occurred at the police station where he was required to report on a weekly basis. The interview - in effect a casual conversation - was in the form of a typed summary to which was attached a 'risk assessment'. The assessment stated: ‘After careful consideration I would consider $\mathrm{O}_{2}$ High Risk of causing Serious Harm.'

His counsel objected to the submission of both reports on the grounds that the information was obtained by deception, that it was served late, that experts were unable to examine and comment on it and that counsel had not been able to take instructions from $\mathrm{O}_{2}$ about the interview. The exchange between $\mathrm{O}_{2}$ 's counsel (X) and counsel for the SSHD (Y) sets out the issues involved:

\footnotetext{
${ }^{47}$ In England and Wales, counsel for the defense is normally composed of the instructing solicitor (she interviews her client, takes his evidence, prepares his statements and takes his instructions) who in turn 'instructs' a barrister. It is the barrister's job to advocate on behalf of his/her client before the court (by taking him and his witnesses through their written evidence, cross-examining prosecution witnesses, and making oral and written submissions to the court).
} 
$\mathrm{X}$ : I ask that it [the report and assessment] be excluded. My position is that $\mathrm{O}_{2}$ has nothing to hide. He has provided eight statements and has indicated his willingness to give oral evidence. The evidence should be adduced fairly.

Y: One task of the Home Office is in relation to a consideration of the evidence to support the individual and whether it will undermine the case ... The process may produce evidence that may help the Secretary of State [...] that information must be disclosed. [In relation to notes of the interview:] The only challenge could be that they are inaccurate or that disclosure is late [...] The risk assessment is of a different nature. But given that risk assessment is what the court does, it is important for the court to consider it... It would be inappropriate to rule it out on grounds of evidence.

$\mathrm{X}:[\ldots]$ There are no provisions for this document. Its circumstances are wholly unfair [...] It causes us prejudice...'

The judge read both documents and, following a submission in closed session, ruled the following day that:

There is no general principle of English law that in civil proceedings ...that evidence obtained by a trick must be excluded to the extent that the admissibility of such evidence involves the exercise of discretion. I propose to admit the notes of interview in evidence [...] but the weight which should be attached to it will of course have to reflect the circumstances of how he came to be interviewed [...]. As to the risk assessment, I believe I should only take it into account [...] if the officer who wrote it is made available for questioning [...]

At this point Counsel for the SSHD stated that he would not call the police officer to give evidence (this appeared to me to be an attempt by the SSHD to frustrate the appeal).

The Monday session resumed with counsel for the SSHD (Y) addressing the judge about the nature of control order hearings (it was the first control order hearing that the judge had presided over). At 11: 27 counsel for the SSHD summarized the ‘open’ evidence against $\mathrm{O}_{2}$. At 12:12 pm a Home Office official was called to give evidence regarding why the SSHD changed the restrictions imposed on $\mathrm{O}_{2}$ and why they refused to vary the restrictions. An hour lunch was followed by a two-hour afternoon session at which 'Witness T' - a member of the security services - gave evidence for the SSHD from behind a curtain. 
The ability of O2's counsel to cross examine ' $\mathrm{T}$ ' was constrained by what the witness was willing to say in open court. However, it soon became clear that his answers, indeed, his willingness to provide information, were shaped by his view of O2. Cross-examination revealed that the witness was, if not hostile, then certainly antagonistic towards $\mathrm{O}_{2}$. Indeed, he refused to comment on a range of questions: (a) on the grounds that the information could not be disclosed; (b) because he assumed that, if relevant legislation had been enacted, that 02 would have been subject to a criminal conviction $^{48}$; and (c) sometimes he did not know the answer (but rather than say this, he refused to comment and had to be specifically asked the reason why he refused to answer).

On Tuesday it emerged that the Security Services’ contention was that $\mathrm{O}_{2}$ 'may have had a general idea' about the failed attack 'but we accept that he may not have known specifics'. Even so because of the 'extremist company' he kept it was proper that the SSHD should make him the subject of a non-derogating ${ }^{49}$ control order. Because the SSHD had refused to disclose whether it was her case that $\mathrm{O}_{2}$ had participated in terrorist training in Somalia, O2's counsel anticipated this allegation and had asked that the SSHD to issue a visa for $\mathrm{O}_{2}$ 's wife and brother-in-law to travel to the UK from Ethiopia to give evidence. However, the SSHD refused to issue them visas which 'blocked the entry of potentially significant witnesses'. Counsel for the SSHD belatedly conceded that $\mathrm{O}_{2}$ was not alleged to have taken part in terrorist training in Ethiopia.

\footnotetext{
${ }^{48}$ It is important to note that some of the actions attributed to the defendant, and explored during the appeal, were not illegal at the time.

49 The PTA 'creates two types of control order. The first is compatible with Art. 5 of the European Convention on Human Rights and can be made by the Secretary of State; this is called a non-derogating control order. The second type is not compatible with Art. 5 and has to be made by a court on an application by the Secretary of State; this is called a derogating control order' (Sec. 1 of the PTA 2005). The conditions imposed by a non-derogatory control order must not 'unduly restrict' an individual's liberty.
} 
From Tuesday afternoon through to late Thursday, the court heard evidence in closed session. Open session resumed at 3:30 on Thursday to hear evidence from the first of two witnesses called by $\mathrm{O}_{2}$ 's legal team. After being sworn in on a Koran, counsel for $\mathrm{O}_{2}$ took Witness $\mathrm{A}$, who had been issued a summons requiring him to come to court, through his written statement. The witness - who had met $\mathrm{O}_{2}$ at a camp in England where the SSHD alleged that military training had occurred - was cross examined by counsel for the SSHD in a manner calculated to undermine his testimony. He was asked why he did not want to give evidence - the witness had been remanded in prison for 18 months on terrorist charges only to be acquitted - and was accused of covering up what had happened at the camp. This line of questioning led to a heated exchange in which the witness sought to refute allegations that he was a terrorist, only to be confronted by accusations that some of his 'associates' on the camping trip had, subsequently, been deported and/or arrested under terrorist legislation.

Counsel for the Home Office (Q) questioned 'Witness A' about his 'associates' and about what occurred on the trip:

'Q. Did you hear anybody talking about extremist activities or extremist views?

A. You have to define what you mean.

Q. Well, let me ask this question: did you hear anybody talking about using violence or about the desirability of using violence?
A. No.

Q. Sorry, I did not hear that?
A. No.
Q. Did you hear anybody talking about jihad? 
A. We all talk about jihad, but you have to understand what jihad is. If you want to say jihad is violence - you have to understand what jihad is and unless you want to explain or I'll explain what jihad is, as far as my knowledge is.

Q. Well, could you explain to his Lordship what you think jihad is?

A. Well, jihad ${ }^{50}$ is a very simple term in Arab language. It just means to strive, so in other words you can strive to do many things. You can strive to make yourself a better person by being humble, you can strive to - jihadist's strive in many ways, so if people want to try and put the spin on it jihad means holy war, it doesn't mean that at all, because I know that's what's been used in common parlance, that people say jihad is holy war. It's just not. Jihad is just a struggle and the greatest jihad is the struggle with yourself. That's one view of Islam.

Q. So can we take it that you would reject the idea of violent jihad?

A. Would I reject it? Well, I mean, it's a fact in Islam that it happens, so I can't reject it. It's a part of Islam, isn't it, so ...

Q. Do you think it is right?

A. Do I think what is right?

Q. Violent jihad?

A. I think that what is written in Islam is right, according to the principles in Islam.

Q. Now, a number of the people who were at the camp in early May 2004 went on to do violent things, did they not?

A. That is what I've heard, yes.

Q. Now that you know that, do you agree with what they did?

A. What, to try and kill innocent people?

Q. Yes.

${ }^{50}$ The concept is not simple. The Encyclopedia of the Quran interprets jihad as 'struggle, or striving, but often understood both within the Muslim tradition and beyond it as warfare against infidels ... The term jihad derives from the root j-h-d denoting effort, exhaustion, strain'. Because numerous verses or sura have been added to the Koran over time, the term has acquired a number of meanings. For example, it may also refer to (a) combat against one's own desires and weaknesses, (b) perseverance in observing the religious law, (c) seeking religious knowledge, (d) obedience to God and summoning people to worship and so on'. 

A. Of course I don't.
Q. Sorry.

\section{A. Of course I don't.}

Q. And then there are a number of people, of other people who were in the camp, who have now been convicted in relation to terrorist training, if I can put it broadly. That is right is [it] not?
A. What's right?
Q. That a number of other people who were on the camp have been convicted of terrorist training?

A. Yes, they have been convicted of terrorist training, yeah.

Q. Do you agree with that? Sorry, the providing of terrorist training?
A. No, of course I don't.
Q. But there are a lot of people at this camp who have subsequently gone on to do things that you disagree with, yes?
A. Yes.
Q. But you never heard or saw or suspected anything untoward during the whole of this weekend? A. No, because nothing untoward happened and the fact of the matter is that
nothing untoward happened. You know this very well, nothing untoward happened. You know this very well. You don't need to be trying to nudge nudge, wink wink, you know very well that nothing happened there, and you can tell the court that. You can be honest and upright and tell the court that nothing happened there because you know this; because the reason why you know this is because you've had intelligence reports because they were watching us, so you know nothing ever happened [...]
In fact, counsel for the SSHD was eliding several separate events together when he referred to 'the camp'; the convictions he was referring to arose out of a 
camping trip that $\mathrm{O}_{2}$ did not attend. The cross examination ended as it had begun, with an accusation which discredited the witness. ${ }^{51}$

Thus, shortly after the above exchange counsel for the SSHD (Y) said:

Y: Mr. B, I suggest to you that what you have been describing about the May 2004 camp is an attempt to cover up what was happening there.

Witness: Is that your suggestion?

Y: Yes. What [do] you say to that?

Witness: Well, this is what I say to that: this is your suggestion and your suggestion is based on nothing ... because the facts of the matter are - and these are the facts which was explained in Woolwich Crown Court. These are the facts which are on record. Surveillance teams were watching us ... They have photographic evidence of us, many, many CDs worth, which I have seen ... So your suggestion is just that, a suggestion, because you wish to spin on something just for the benefit of yourself ...'

The above exchanges were significant. First counsel deliberately sought to provoke the witness by bringing up the charges made against him under the PTA. This inflamed ' $A$ ' who became quite hostile and had the effect of eliciting statements which undermined the value of his testimony. Furthermore, many of counsel's questions were general in nature and did not relate to specific events or to $\mathrm{O}_{2}$ which witness 'A' might reasonably have addressed. Indeed, counsel’s questions exploited popular stereotypes about Islam, e.g., jihad as ‘violent' and as a justification 'to try and kill innocent people'. Counsel for the SSHD did not seek to obtain new information to assist the court - he sought only to incriminate the witness and reduce the value of his testimony. This tactic was unnecessary because the low standard of proof meant that his testimony could easily be undermined by establishing a 'link' to individuals who had been charged with terrorist offences after the camping trip.

${ }^{51}$ Clearly this type of proceeding is adversarial, as occurs in criminal proceedings, and reflects attempts by counsel for the SSHD to secure a conviction. However, since the SSHD relies on undisclosed, 'secret' evidence, it might well be asked whether they are appropriate in this type of case. 
Some information provided in the closed sessions was released on Friday morning in the form of a 'gist' (a note) which summarized the evidence Witness $\mathrm{T}$ had given. The one page 'gist' (summarized in Box C) relates to Home Office allegations about O2’s visit to Somalia.

\section{Insert box $\mathrm{C}$ here}

The disclosure led $\mathrm{O}$ 2's counsel to instruct me to write a second report addressing the 'gist'. My seven-page report - which discussed the substantial flow of people/refugees moving across the Ethiopia-Somalia border and anthropological data about ethnicity, language and 'racial' differences between Somali's and Ethiopians was submitted to the court the following Monday.

The proceedings on Friday morning involved a two-hour session in which Witness B, the wife of one of $\mathrm{O}_{2}$ 's associates who had accompanied him on the trip to Somalia, gave evidence. Counsel for the SSHD questioned her about her husband, his behavior, his associates and why he had gone to Somalia. However, she said that her husband only told her he was going to Somalia the day before he left and that while she knew $\mathrm{O}$ 2's mother, she did not know him or his siblings. She was unable to provide much information. Counsel for $\mathrm{O}_{2}$ attempted to clarify her evidence but the only relevant facts which emerged from her testimony was that her husband was a devout Muslim and that he did not tell her about his friends, activities or the trip to Somalia.

Friday afternoon was spent taking O2’s testimony. This began with his counsel taking him through key issues ${ }^{52}$ in his ten statements and ended with questioning him

\footnotetext{
52 The issues were: his last visit to Ethiopia; his visit to Mogadishu; the inability of his family to visit him in northern England where he had been compelled to live because of the control order; his response to an amended statement by the SSHD and his relation to an 'extremist'; his response to questions put to him by the SA; issues in
} 
about the statements made in the 'gist' concerning his activities in Somalia which he sought to refute. During this two-hour period, $\mathrm{O}_{2}$ was repeatedly asked if he had been involved in any (para-)military training, which he denied; he clarified key issues and denied all the allegations made against him by the SSHD.

I turn now to key issues which arose from counsel for the SSHD's three-hour cross-examination of $\mathrm{O}_{2}$ on Friday afternoon. The cross examination consisted of 421 questions and the answers they elicited. Six themes emerged from my analysis of this exchange of which the first (immigration controls in the Horn) and the last ( $\mathrm{O}_{2}$ 's departure from Somalia to Ethiopia) were unimportant (as defined by the small number of questions; fifteen and nine, respectively, and the fact they did not figure in judge’s subsequent decision).

Questions are used to obtain evidence and, depending on the jurisdiction and the ability of the lawyer, they can be used to 'control' a witness by discursively compelling him to make an admission and incriminate himself. ${ }^{53}$ Questioning in the context of a court room reflects the power of the court over those who are called to give evidence; it is a means of control reserved for those with recognized legal authority.

The first substantive issue pursued concerned O2's 'friends'. Counsel used interrogatives and declaratives - as opposed to open questions allowing the defendant

relation to the SSHDs refusal to modify his control orders and recent amendments in a security service statement about him; issues in response to further open material served by the SSHD; finally, his response to the circumstances in which he had been informally interviewed by the police and his comments in the police report.

${ }^{53}$ S. Harris, 'Question as mode of control in magistrate's courts', International Journal of the Sociology of Language 49 (1984, 10-f) notes that iinterrogative questions 'may be built in such a way as to elicit certain preferred answers, and hence create difficulties for witnesses to disagree'. Such questions can only be answered by a simple 'yes' or 'no' and they are used to elicit specific information from a witness to explain their behaviour. It is very difficult for defendants questioned in this way to introduce new topics or to redefine the questions they are asked. See also C. Briggs, Disorderly Discourse. Narrative, Conflict and Inequality (University Press: Oxford, 1996). 
to redefine the question or provide his own answer - to compel $\mathrm{O}_{2}$ to provide affirmative answers ${ }^{54}$ which 'linked' him to a number of 'extremists' ${ }^{55}$ thereby underlining the 'reasonableness' of the SSHDs decision to impose a control order on him.

Questioning also focused on the conviction of members of his family for terrorist-related offences (four questions), before turning to his alleged relationship with convicted 'Islamic extremists' (29 questions). Counsel used disjunctive questions ${ }^{56}$ in which $\mathrm{O}_{2}$ was asked about his relationship to individuals named in his witness statements. Among the issues addressed was $\mathrm{O}_{2}$ 's presence at the house of 'M' who had subsequently been convicted of terrorist-related offences. While $\mathrm{O}_{2}$ was able to explain his presence at M's house, he was compelled to acknowledge that he had socialized with Muslims there. This admission was tied to hear-say evidence ${ }^{57}$ from an undercover police officer who had attended similar meetings at M's house, albeit not the meetings attended by $\mathrm{O}_{2}$, that 'jihad' ${ }^{58}$ was a subject of discussion.

\footnotetext{
${ }^{54}$ Harris, Questions as mode, 10-f.

${ }^{55}$ Including his brother-in-law who was later convicted of a terrorist offence. $\mathrm{O}_{2}$ hotly disputed' 'links' to 'Islamic extremists' (including to individuals who were subsequently charged and convicted; some who were charged and acquitted; some who were excluded from the UK; and some whom he disputed that he had any link to).

${ }^{56}$ Disjunctive questions are those which can only be answered by a 'yes' or 'no'. 57 The basic rationale for the rule of excluding hearsay evidence concerns the need to assess the evidence to see 'what, if any, weight can be given to a statement by a person whom the jury have not seen or heard and which has not been subject to any test of reliability by cross-examination' (P. Murphy, Blackstone's Criminal Practice. (Oxford University Press: Oxford. 2005, 2425). However, in closed material proceedings there are no rules of evidence other than excluding evidence obtained by torture. In O2's 2010 appeal against his proposed deportation to Ethiopia, SIAC relied on evidence obtained by British security officials about conditions in Ethiopia's secret detention centers where foreign nationals who had been subject to extraordinary rendition had been held SIAS concluded that O2's rights would not be violated if he were returned to Ethiopia.

${ }^{58}$ See footnote 48 .
} 
The focus shifted to the 2004 camping trip (sixty-seven questions). O2 went on the trip at the suggestion of his brother-in-law and they took his six-year old nephew. Was it a social occasion, asked counsel? Was this an opportunity to make new friends? No, said $\mathrm{O}_{2}$, 'it was an opportunity for me to go camping'. Apart from asking him about what occurred during the trip, the nature and tenor of the questions intimated that the campers had planned terrorist attacks and had undergone military training. Indeed, counsel's questions were based on hearsay evidence which derived from the observations of off-duty police officers - in a report written two years after the incident ${ }^{59}$ - that some individuals at the camp were 'punished'. Officers described seeing individuals 'dressed identically in black outward-bound fatigue type clothing' who were being shouted at by an 'instructor or leader' who 'controlled the group'. The inference which counsel was asking the Judge to make was that 'punishment' of the kind described must have been 'military' training.

The line of questioning switched to his marriage, his wife's pregnancy (information about which he expressed little knowledge), his trip to Ethiopia in early 2005 and his intention to return to Ethiopia for the birth of his son (one hundred fortytwo questions). It was here that Counsel questioned the circumstances surrounding Oz's decision to go to Somalia with friends rather than travel to Ethiopia to attend the birth of his son. Didn't he realize how dangerous Somalia was? What was his role in planning the trip to Somalia? Counsel specifically asked him why he had not informed his family about his intention to travel to Somalia. Counsel began by asking $\mathrm{O}_{2}$ whether he perceived that the trip to Somalia might be 'dangerous', an assertion which $\mathrm{O}_{2}$ rejected.

${ }^{59}$ The admission of hearsay evidence written up two years after the alleged incident would appear to violate the most basic rules of evidence which concern, in this instance, a serious lapse in time between the alleged incident and the writing of a report about the incident. See Rule 602 of the US Federal Rules of Evidence at: https://www.law.cornell.edu/rules/fre/rule_803 
Q: 'You are going to be safe?

A. Yeah.

Q. So there was nothing to worry about from that point of view. So you could tell your mother and your family that you were going to go to Mogadishu, could you not?

A. Are you talking about from the safety point of view or from them ...

Q. From any point of view.

A. No, if they were going to prevent me, they'll prevent me from going.

Q. No, there was nothing to prevent you telling them that you were going to Mogadishu?

A. Except that they would tell me not to go, that's the only reason why I didn't tell them.

Q. But they could not have stopped you going?

A. No, they would have told me, look, go to Ethiopia. My mum, she would cry, you know what I'm saying, yeah: "look, I raised you up, your dad used to do this", start crying, you know what I'm saying. You understand? So because of that, yeah, I didn't want to tell them. If I told them they would have talked me out of it.

Q. Well, that would be because your mother was expecting you to go to Ethiopia.

A. Yes, and never heard of me planning go to Somalia [...]'

There followed a brief discussion about another issue before counsel returned to his original line of questioning:

Q. 'So let us see if we can come back ...

A. So the reason why I mentioned Egypt to her, yeah, because previously she knew about Egypt.

Q. Well, your mother's objection was that you were not going to Ethiopia and you were going to be going to somewhere else?

A. Yeah, to Egypt. 
Q. Well, her objection was, was it not, that you were not going to Ethiopia and that is where she thought you should be going. That's right, is it not?

A. Yes.

Q. And so it didn't really matter where the other place was, whether it was Egypt or Barbados or Somalia. That is right? You would get the same reaction from her.

A. Yes.

Q. So why did you not say to her, well, actually I am going to Somalia?

A. No, because I'm going to go ... like, because, you know, the Egypt thing, she knew that I considered it and stuff like that, yeah, and I told it was for only eight weeks, yeah, and, you know, it's a good opportunity for me to go, basically. I lied to her, you understand, yeah, and that's it. I made up my mind, that's what happened.'

$\mathrm{O}_{2}$ conceded that he had lied to his mother and family about going to Somalia because he went on the spur of the moment. This admission was seized upon by counsel for the SSHD who argued that if the purpose of the trip was really for religious purposes, why 'lie' about it to his family?

At various points counsel deliberately inflamed $\mathrm{O}_{2}$. While both parties were frustrated by their inability to pursue or answer questions, O2's inability to provide clear answers and to provide independent corroboration to support his account undermined his evidence.

The afternoon concluded with $\mathrm{O}_{2}$ being briefly re-examined by his counsel about the camping trip, planning the trip to Somalia and the views of his UK-based Somali friends who discounted any danger of visiting Mogadishu. O2’s counsel concluded with questions pertaining to his social isolation which arose from his forced relocation to northern England because of the modified control order.

\section{The work of the courts}

The procedural and evidential rules established in the PTA and related terrorist legislation place the Secretary of State and the defendant on a very unequal footing 
and they require the judge to assess open and closed evidence. Second, given the limited extent to which a Special Advocate can assist an appellant, the onus for ensuring that legal proceedings are conducted fairly falls on the judge who decides on the admissibility of all the evidence. This legislation bears the imprint of three decades of emergency/terrorist legislation aimed at suppressing terrorism in Northern Ireland by single judges (i.e., the 'Diplock Courts'), ${ }^{60}$ a fact which must surely explain why the effectiveness of adversarial challenge during the open sessions is so ineffective. If my conclusion is correct, then adversarial challenge by the Special Advocate in the closed sessions must have been practically useless to 02 . However, we will never know the effectiveness of the SA because the proceedings were closed (nor is there a published record) and the court only requires sufficient evidence to support the SSHD's suspicion that $\mathrm{O}_{2}$ was associating with 'terrorists'.

In this type of case the Judge must assess whether the SSHD has reasonable grounds for suspecting ('believing' in the case of TPIMs) whether the defendant has been involved in terrorist-related activity (which is not even a balance of probabilities test $)^{61}$ and whether s/he is likely to pose a threat to national security. This assessment works by establishing 'links' between a defendant and 'terrorists'.

${ }^{60}$ B. Dickson, 'Northern Ireland emergency legislation - the wrong medicine?', Public Law (Winter, 1992) 592-624.

${ }^{61}$ In Re B [2008] UKHL 35) Lord Hoffman answered the question of how to decide a case on the balance of probabilities using a mathematical analogy: "If a legal rule requires a fact to be proved (a 'fact in issue'), a judge or jury must decide whether or not it happened. There is no room for a finding that it might have happened. The law operates a binary system in which the only values are 0 and 1 . The fact either happened or it did not. If the tribunal is left in doubt, the doubt is resolved by a rule that one party or the other carries the burden of proof. If the party who bears the burden of proof fails to discharge it, a value of 0 is returned and the fact is treated as not having happened. If he does discharge it, a value of 1 is returned and the fact is treated as having happened." At: https://uk.practicallaw.thomsonreuters.com/2-5006576?transitionType=Default\&contextData=(sc.Default)\&firstPage=true\&bhcp $=1$. This is a civil, not a criminal, standard of evidence, which means that more than 50 percent of the evidence must be accepted by the court. 
In a thirty-six-page decision, the judge made it clear that in assessing the closed evidence he required the SSHD either to disclose certain evidence or withdraw it (the SSHD decided not to disclose). He accepted evidence obtained by a trick and all the hearsay evidence as providing a sufficient reason to be skeptical of $\mathrm{O}_{2}$ and of witness A’s testimony. Skepticism was, he thought, justified because some of the individuals at the events attended by $\mathrm{O}_{2}$ had subsequently been convicted of terroristrelated activities while others had been excluded from the UK. The judge argued that 'there are a number of reasons to be very skeptical' about O2's account of the trip to Somalia and the groups stated intention of doing 'free-style dawah' because Somalia was not a safe place to go.

Critically Oz's 'reticence with his family’ about going to Somalia led the judge to conclude: 'One is entitled to suspect that he concealed the fact that he was going to Somalia in order to hide what he was really intending to do there [...] the justifiable suspicion arises that what he was hiding was the jihadist training which he went to Somalia for.' Furthermore, the absence of any independent evidence concerning his visit to Somalia was damning: '...$(T)$ he fact that he was able to provide a general description of some of the mosques in Mogadishu does not mean that he stayed in them. He could just as easily have visited them to pray while he was in Mogadishu undergoing terrorist training.'

In relation to his 'links with Islamic extremists, the judge noted that: 'This is not so much a case of guilt by association. Rather his connection with so many people associated with extremism makes it much more difficult to treat what might otherwise be normal activities, such as going on a camping trip, as innocent.' The judge concluded,

The many parts of the jigsaw to which the analysis [...] above relates have combined to create a worrying profile of $\mathrm{O}_{2}$. I agree with the assumption 
underlying the control order, namely that the evidence (at any rate the open evidence) does not justify charges relating to any particular criminal activity being laid against $\mathrm{O}_{2}$. Any terrorist training which the evidence suggests he would have undergone took place before terrorist training was criminalized. But each of the core features of the Secretary of State's case raises suspicions in themselves to a greater or lesser degree, and when combined together they serve to increase one's misgivings about him. Everyone agrees on the importance of considering both the open and the closed materials together since the latter may have the effect of making the open case less strong than might appear at first sight. But even if such parts of the closed materials as might be regarded as exculpatory are taken into account, I have concluded that the facts relied upon by the Secretary of State in the open materials [...] amount to reasonable grounds for suspecting that $\mathrm{O}_{2}$ has been involved in terrorism-related activity, as defined in sections 1(1)-1(4) of the Terrorist Act 2000 and section 1(9) of the 2005 Act.' [my emphasis].

Oz's counsel appealed against this decision to the Court of Appeal where it was heard in the spring of 2009. It took the Lord Justices less than 30 minutes to dispose of the appeal. Lord Justice W concluded that it could be seen from the determination that 'the judge was putting all the matters together to see if the facts corresponded with the assumptions of the control order that there was a suspicion of evidence of terror related activities'. In relation to the apparent contradiction between the evidence of Witness T and my expert report dealing with the 'gisted'/disclosed information, the Lord Justices noted that the judge had 'considered' both reports so 'what has he [the judge] done wrong?' They allowed an appeal solely on the basis that Oz's human rights may have been violated when he was relocated to northern England. ${ }^{62}$ The hearing bore all the marks of a 'ritual' in the sense that the Lord Justices, the legal teams for both sides and the SA went through the formality of an appeal knowing that the PTA made it impossible to defend an individual against 'reasonable suspicion' of involvement in terrorist related acts.

In early 2010 the SSHD sought to deport $\mathrm{O}_{2}$ - who had by this time, and out of frustration with being internally exiled, been convicted and prisoned for breaching his control order - to Ethiopia. The SSHD sought to deport him using a newly negotiated

\footnotetext{
${ }^{62}$ The Supreme Court overturned this decision in a subsequent appeal in 2010.
} 
'Memorandum of Understanding'. ${ }^{63}$ Her decision triggered an appeal which focused on Oz's rights under the European Convention of Human Rights. The Court decided that it was satisfied with the diplomatic assurances that $\mathrm{O}_{2}$ 'will not be subjected to treatment' contrary to the ECHR and that the British Government would not be in breach of its obligations under the ECHR. However, O2 remained in prison until 2013 at which time, to end his indefinite incarceration, he asked to be deported.

\section{Conclusion}

The PTA and associated legislation has given rise to a growing number of appeals challenging the use of secret evidence all of which highlight the courts limited power to review the SSHD's decisions on control orders. While it has long been known that the decisions made in closed proceedings are subject to 'extra-ordinary weaknesses', ${ }^{64}$ the British courts have shown a surprising reluctance to find fault with terrorist legislation. ${ }^{65}$ It was not until February 2009 when the European Court of Human Rights decided 'A and Others $v$ The United Kingdom' 66 - a case involving 11 individuals held under control orders - that the British courts were forced to rescind

${ }^{63}$ Regardless of the fact that Ethiopia had a very poor human rights record, see: 'Letter to the British Foreign Secretary regarding diplomatic assurances (on Ethiopia)' (17/9/2009) at: http://www.hrw.org/news/2009/09/17/letter-british-foreign-secretaryethiopian-deportation-cases

${ }^{64} \mathrm{G}$. Van Harten, 'Weakness of adjudication in the face of secret evidence', International Journal of Evidence \& Proof 13 (2009), 3.

${ }^{65}$ For a review of a case similar to that of $\mathrm{O}_{2}$, see 'R (AN) v Secretary of State for Justice [2009] EWHC 1921 (Admin), judgment of 28 July 2009’. For a broader review of SIAC procedures see House of Lords 'RB (Algeria) (FC) and another (Appellants v SSHD (Respondent), OO (Jordan) (Original Respondent and Crossappellant) v SSHD (Original Appellant and Cross respondent) 2009 [UKHL] 10, judgment on 18 February 2009].

${ }^{66}$ See $\$ 220$ and passim of http://www.asylumlawdatabase.eu/en/content/ecthr-andothers-v-united-kingdom-application-no-345505-19-february-2009. This case, which involved the lengthy deprivation of liberty, required the SSHD to disclose a core irreducible minimum of the case against a defendant to give meaningful instructions to the SA. The decision saw the SSHD withdraw some control orders rather than disclose even a minimum of information. 
earlier decisions upholding the procedural fairness of hearings which relied on closed evidence. $^{67}$

While the ECHRs ruling forced the SSHD to rethink her policy on the use of secret evidence ${ }^{68}$ it did not affect $\mathrm{O}_{2}$ because in his case the court had relied on open material to reach a decision. Even so, reliance on disclosed evidence in the form of a 'gist' is very difficult for appellants to respond to because it requires independent corroborative evidence about events which, by their very nature, are difficult to obtain independent corroboration for. Furthermore, individuals held under a control order/TPIM are barred from seeing their friends and associates, and the latter are naturally reluctant to associate with the individual or provide evidence (as was the case with Witness A).

The Terrorism Prevention \& Investigations Measures Act (2011) and associated legislation ${ }^{69}$ is much more pre-emptive in nature than earlier counter-terror

\footnotetext{
${ }^{67}$ It is instructive to compare the Canadian Supreme Court's approach to the use of the Art 1F 'exclusion clause' which, until 2013, relied upon similar reasoning to that applied in the British courts with respect to terrorism, namely that a person found to be 'complicit' in a crime could be excluded from Protection. In Ezokola $v$ Canada [2013] 2 S.C. $R$ the Supreme Court overturned the existing test and replaced 'the personal and knowing participation test' with a 'contribution-based approached to complicity.' It is now necessary to establish a voluntary, significant and knowing contribution to the organization's crime or criminal purpose. Guilt by association is no longer enough to exclude an individual from the protection of the Refugee Convention (though a low evidentiary standard is used in Canada than in the UK). See: L. Waldeman \& W S. Meighen. 'An Analysis of post-Ezokola and JS Jurisprudence on Exclusion', in I. Atak \& J. S. Simeon. Eds. The Criminalization of Migration. Context and Consequences (McGill-Queen's University Press: Montreal. 2018), 138-167.

${ }^{68}$ See: 'Home Secretary orders review of control orders for terror suspects' (The Guardian, 16 September 2009), and 'Terror suspect freed from control order' (The Independent, 24 September 2009).

${ }^{69}$ Specifically the 'Justice and Security Bill HL (2012-13)' (which provides for closed material procedures in certain civil proceedings and prevents the court from disclosing sensitive information), the 'Enhanced Terrorism Prevention and Investigation Measures Bill (Cm 8166) currently before Parliament (which would allow the SSHD to impose more stringent restrictions on individuals served with a TPIM notice) and the 'Human Rights 1998 (Repeal and Substitution Bill) 2011-12' before Parliament.
} 
legislation in that it builds on the Counter-Terrorism and Security Act (2015) by extending 'coercive non-trial-based measures aimed at terrorist suspects generally, but particularly at persons who have gone abroad to support ISIS or who may seek to do so’ by creating ‘Temporary Exclusion Orders’ (TEOs). TEO’s are used by the SSHD to prevent British nationals from entering the UK for up to two years (a form of enforced exile) while the individual is investigated. The bill also introduced 'strengthened TPIM measures'. ${ }^{70}$ Whereas TPIM notices replaced control orders ostensibly with 'a more focused and less intrusive system of terrorism prevention and investigation measures’ (so called ‘light-touch measures’), ‘enhanced TPIMs’ rely on CMPs, SAs and the right to impose conditions which mirror the measures imposed on $\mathrm{O}_{2}$.

What does $\mathrm{O}$ 's case allow us to infer about the potential impact of current counter-terrorist legislation? It is clear that the reforms have strengthened the power of the state over the rights of individuals. Notable omissions from the legislation include a refusal to end the state’s reliance on intercept 'evidence', ${ }^{71}$ continued reliance on Closed Material Proceedings ${ }^{72}$ (with their dependence on SA's to ensure fairness in a context in which it is impossible to know if they have fulfilled their responsibility and in which the court has limited power to quash a control/TPIM

\footnotetext{
${ }^{70}$ Whereas individuals with the right to abode in the UK can, eventually, be deported, citizens cannot be deported or stripped of their citizenship; a TEO allows the SSHD time to consider the case against a citizen suspected of terrorism. See: H. Fenwick, 'Responding to the ISIS threat: extending coercive non-trial-based measures in the Counter-Terrorism and Security Act 2015', International Review of Law, Computers and Technology 30, 3 (2016), 174-190.

${ }^{71}$ Intercept information is not allowed in criminal or civil proceedings but is the basis of accusations and findings in control order/TPIM cases.

${ }^{72}$ In the UK it appears that the courts, Parliament and citizens are more willing to accept the need for 'secret trials' than is the case elsewhere. What does this acceptance reveal about our society, our fear of others and the need to ensure our 'security' if it comes at the expense of justice?
} 
order), and a failure to amend/repeal other anti-terrorist laws such as Sec. 19 of the Terrorist Act (2000) which was used to convict O2’s family.

The new laws do not restrict the power of the SSHD even though The Independent Reviewer of Terrorist Legislation had proposed a scheme that would allow a court to lift restrictions against suspected individuals where 'the Home Secretary had reasonable grounds to believe that a named individual is engaged in terrorist activity and, in the view of the Director of Public Prosecutions, a criminal investigation into that individual is therefore justified'. ${ }^{73}$ In short, the Home Secretary retains the power to impose and sustain measures similar to those $\mathrm{O}_{2}$ experienced.

Given the impact of other legislation and a substantial blurring of boundaries between civil and criminal law, it should be clear that existing legislation undermines the right of individuals to defend themselves against a TPIM notice. Secret trials, with all they entail regarding the erosion of a right to a fair trial, are set to remain an important part of the way in which the government proceeds against individuals who are suspected, but about which little evidence exists, of involvement in terrorism. It should also be remembered that the government withdrew its key claim against $\mathrm{O}_{2}$ that he knew about, and was therefore complicit in, planning a terrorist attack in London. At no point in the open evidence was the argument made, and sustained, that $\mathrm{O}_{2}$ contributed to planning or carrying out the attack.

The SSHD has promised not to 'park' - i.e., fail to progress - cases for more than two years and to attend to the reports of the 'Independent Reviewer of Terrorism Legislation' but, if the experience of the outgoing Reviewer, Lord Carlisle, was anything to go by, the Government finds it easy to ignore unpalatable comments about

\footnotetext{
${ }^{73}$ Lord Macdonald, Review of Counter-Terrorism and Security Powers (Command paper 8003. London, 2011). Emphasis in the original.
} 
the impact of restrictions or the length of control order/TPIM notices (see Carlisle 2009). ${ }^{74}$

Were ' $\mathrm{O}_{2}$ ' able to comment, what might he say? First, he would complain about the many powers of the SSHD - e.g., the ease with which she can remove/reinstate his ILR, the ease with which his case was 'parked' and the consequent social isolation imposed on him and his family, etc. Second, he would draw our attention to the shortcomings of his appeals, notably his inability to know and answer the charges against him, the courts admission of evidence obtained by a trick, its acceptance of hearsay evidence and the fact that he was found 'guilty by association' with individuals which the SSHD deported or arrested.

In relation to the supposedly reduced restrictions that could be imposed under a TPIM notice - i.e., replacement of curfews by 'overnight residence requirements', 'greater access' to communications, greater freedom to associate, freedom to study and work, etc. - I suspect that $\mathrm{O}_{2}$ would see these as superficial changes for two reasons. First, once an individual is placed under a control order no one wishes to be associated with him/her. ${ }^{75}$ Secondly, the SSHD retains her power to impose 'enhanced' restrictions. It seems clear that, from the point of view of suspected individuals placed under them, control orders/TPIM notice are intended to isolate and punish individuals who the SSHD believes - but about whose activities there is no clear evidence - may be involved in terrorism-related offences. ${ }^{76}$

\footnotetext{
${ }^{74}$ At a speech at the Institute of Advanced Law in February 2008 Lord Carlisle referred to the role played by political parties in Parliament who were the force behind the 'pragmatic incrementalism' which was driving the expansion of terrorist legislation which served as an impediment to reviewing and consolidating legislation. ${ }^{75}$ As Cerie Bullivant discovered, see: http://www.liberty-humanrights.org.uk/materials/control-orders-case-study-cerie-bullivant.pdf (accessed 11 February 2011). Also see A. Carlisle, Fourth Report of the Independent Reviewer pursuant to Sec. 14(3) of the Prevention of Terrorism Act 2005. (February). 2009. ${ }^{76}$ As Lord Hoffman observed, see footnote 17.
} 
To be sure $\mathrm{O}_{2}$ 's views were evident to his lawyers and, to a more limited extent, to the judges - who are appointed to the Bench following a successful legal career - who presided over his many appeals. It should be clear, however, that by dint of their training lawyers and judges tasked with implementing counter-terrorist laws do not seem to encounter serious ethical difficulties with the roles they are asked to play in control order/TPIM cases, i.e., judging by their willingness to take either or both sides in these legal contests. After all, to appear in the High Court, the Court of Appeal and the Supreme Court to argue or decide 'terrorist' cases represents the pinnacle of a lawyer's career. If they experience discomfort with the CMP and the way in which terror suspects are detained, their frustrations take the form of arguing over 'facts' - based on the binary distinction between 'proved' and 'disproved' rather than contesting the fairness of legal proceedings which are conducted professionally but which always uphold the SSHDs imposition of control orders/TPIM measures. To err on the safe side, which is to say assessing a case on the balance of probabilities, that an individual did 'associate' with 'terrorists' is not a problem for lawyers and judges. Advocacy is what lawyers are trained to do in an adversarial system where they act on behalf of their clients. The exception, of course, are Special Advocates who straddle their representational and disclosure roles; however, their ability to perform both roles cannot be assessed which transforms them into chameleons/shape shifters whose professional and ethical responsibilities are poorly defined.

As an anthropologist there is little reason to be sanguine about Closed Material Proceedings because we are taught to see the world differently to lawyers. After having heard all the 'open evidence' it is not evident to me that $\mathrm{O}_{2}$ knew about the terrorist incident which resulted in his lengthy internal exile/detention and the criminal conviction of members of his family. Writing a decade after the case, I find 
that so little evidence was adduced in his appeal that it is not possible for me to unequivocally assign liability for his behavior or to understand whether the accusations made against him had a basis in fact. Unlike lawyers, it appears to me that the parameters used to define 'the balance of probabilities' to allocate liability for wrong-doing are vague and poorly defined; the legal approach relies on identifying potential 'links' between individuals who are said to associate together.

Anthropologists would want to know more about what, if anything, occurred at suspected meetings and we would want independent corroboration to assess conflicting accounts. In short, we tend to question normative and accepted views about assumed behavior, etc.

Equally important, anthropologists are taught to step back from specific disputes to see the wider picture. In the context of Closed Material Proceedings this means looking at the role played by powerful institutions and legal actors in organizing, managing and participating in chameleon like political-legal procedures. Furthermore, whereas in law the concept of causality is inseparable from individual responsibility, anthropologists believe that there are likely to be multiple factors ${ }^{77}$ explaining (criminal) behavior which are not adequately addressed by a legal process that relies on conflicting, uncorroborated or secret evidence. For anthropologists, a 'fact' cannot be understood as true or false. Facts take their meaning from a moral or social universe which the law, which seeks a simple yes or no to assign liability, is not set up to understand.

\footnotetext{
${ }^{77}$ See, for instance: 'Assimilation's Failure, Terrorism's rise' (The New York Times, 6 July 2011) which argues that an obsession with radicalisation misses the point about why 'so many young people, who by all accounts are intelligent, articulate and integrated, come to find this violent, reactionary ideology so attractive.' The writer identifies the source of the problem with the failure of 'multiculturalism' and the failure of government to engage directly with ethnic minorities as citizens (to which should be added the impact of racism and discrimination on young Black and ethnic minority residents and citizens).
} 
In conclusion, anthropology and law operate with different mindsets, assumptions and paradigms such that anthropology - certainly this anthropologist finds it difficult to have confidence in the ability of Closed Material Proceedings to achieve justice. As Nader has observed, anthropologists attempt to see through legal discourse and legal procedure to lay bare and question concepts such as ‘justice’ and the 'rule of law' which, in the case of Closed Material Proceedings against an alleged terrorist, reveals a process that is deeply worrying. If it is true to say that law seeks to use its power to enforce, reflect, constitute and legitimize dominant social and power relations, by contrast the role of anthropology is to unsettle, probe and question the certainties which underlay legal practice/procedure and forms of governance which appear to be profoundly unjust.

\section{References}

Bailey, Freddie G. Stratagems and Spoils. A Social Anthropology of Politics. Schocken Books: New York, 1969.

Briggs, Charles. Disorderly Discourse. Narrative, Conflict and Inequality. Oxford: University Press, 1996.

Brouwer, Evelien. 'Immigration, asylum and terrorism: A changing dynamic. Legal and practical developments in the EU response to the terrorist attacks of 11.09”, European Journal of Migration and Law 4 (2003): 399-424

Boyle, Elizabeth \& Erika Busse. 'Institutional vulnerability and opportunity” Immigration and America’s “War on Terror”, Law \& Social Enquiry 31, 4 (2006): $947-74$ 
Campbell. John. Bureaucracy, Law and Dystopia in the United Kingdom's Asylum System. Routledge: New York, 2017.

Carlisle, Alex (Lord). 2009. Fourth Report of the Independent Reviewer pursuant to Sec. 14(3) of the Prevention of Terrorism Act 2005. (February).

Conley, John, William O’Barr \& E. Allan Lind. ‘The power of language: presentational style in the courtroom', Duke Law Journal (1978): 1375-1399.

Conley, John., \& William O’Barr. ‘Hearing the hidden agenda: The ethnographic investigation of procedure’, Law \& Contemporary Problems 51, 4 (1988): 181-197

Conley, John. 'Review: Can You Talk like a Lawyer and Still Think like a Human Being? Mertz's the Language of Law School', Law \& Social Inquiry 34, 4 (2009): 983-2015

Dickson, Brice. 'Northern Ireland emergency legislation - the wrong medicine?', Public Law (Winter, 1992) 592-624

Epstein, Arnold L. 'The case method in the field of law', in A. L. Epstein. Ed. The Craft of Social Anthropology. Tavistock: London. 1967. Pp. 205-230.

Fenwick, Helen. Responding to the ISIS threat: extending coercive non-trial-based measures in the Counter-Terrorism and Security Act 2015', Int. Review of Law, Computers and Technology 30, 3 (2015): 174-190 
Good, Anthony. 2004. 'Expert evidence in asylum and human rights appeals: An expert's view', Int. Jo. of Refugee Law 16, 3: 358-380

Harris, Sandra. 1984. ‘Question as mode of control in magistrate’s courts’, Int. Jo. of the Sociology of Language 49: 5-27

House of Commons. The operation of the Special Immigration Appeals Commission (SIAC) and the use of Special Advocates. Constitutional Affairs Committee. Seventh Report of Session 2004-05. Vol. 1. Report together with formal minutes. (March 2005).

Hudson, Graham. Behind Closed Doors: The judicial administration of 'secret trials' in Canada. Paper presented at International Association of Forced Migration, Thessaloniki, Greece. 2018.

Jackson, John. 'The role of special advocates: Advocacy, due process and the adversarial tradition', International Jo. of Evidence and Proof 20, 4 (2016): 343-362

Kandel, Randy. 'How lawyers and anthropologists think differently', Annals of Anthropological Practice (special issue: Double Vision - Anthropologists at Law, 1992). Pp. 1-20.

Kavanagh, Aileen. 'Special advocates, control orders and the right to know', The Modern Law Review 73, 5 (2010): 836-857 
Macdonald, Lord. Review of Counter-Terrorism and Security Powers. Cmd paper 8003. London. 2011.

McCulloch, Jude. 'Pre-Crime and counter-terrorism. Imagining a future crime in the War on Terror’, The British Jo. of Criminology 49, 5 (2009): 628-645

Murphy, Peter. Blackstone’s Criminal Practice. Oxford: Oxford University Press. 2005.

Nader, Laura. 'The words we use: justice, human rights, and the sense of injustice', in Mirrors of Justice, K. Clarke \& M. Goodale. Eds. Cambridge University Press: N.Y. 2010, 316-331.

Rawls, John. 1971 [1999]. A Theory of Justice. University Press: Oxford.

Sandell, Adam. 'Liberty, fairness and the UK control order cases: two steps backward, two steps back’, European Human Rights Law Review 1 (2008) 120-131

Van Harten, Gus. 'Weakness of adjudication in the face of secret evidence’, Intntl. Journal of Evidence \& Proof 13 (2009) 1: 1-27

Waldeman, Lorna \& Warda S. Meighen. 'An Analysis of post-Ezokola and JS Jurisprudence on Exclusion', in I. Atak \& J. C. Simeon. Eds. The Criminalization of Migration. Context and Consequences. McGill-Queen’s University Press: Montreal. 2018. Pp. 138-167. 
Wehr, Hans. Ed. A Dictionary of Modern Written Arabic (Arabic-English). Otto Harassowitz: Wiesbaden. 1979.

Woolf, Lord. 'The rule of law and a change in the constitution' (Squire Centenary Lecture), in The Times. (3 March 2004) at:

http://www.timesonline.co.uk/tol/news/article1036741.ece?

Zedner, Lucia. 'Securing liberty in the face of terror: Reflections from Criminal Justice', Journal of Law \& Society 32, 4 (2005): 507-533 